\title{
ANTICUERPOS CONTRA EL VIRUS DE LA PARAINFLUENZA 3 EN CERDOS DE CRIANZA TECNIFICADA Y DE TRASPATIO BENEFICIADOS EN MATADEROS DE LIMA
}

\author{
Antibodies Against Parainfluenza 3 Virus in Pigs from Technified and \\ Backyard Farms Slaughtered in Lima, Peru
}

Milagros Montesinos P. ${ }^{1}$, Hermelinda Rivera G. ${ }^{1,2}$, Mariluz Araínga R. ${ }^{1}$

\section{Resumen}

El objetivo del presente estudio fue determinar la frecuencia de anticuerpos contra el virus de la Parainfluenza 3 (VPI3) en porcinos beneficiados en la ciudad de Lima. Se colectaron muestras de sangre de cerdos de ambos sexos y de 2 a 6 meses de edad, provenientes de granjas tecnificadas $(n=192)$ y de crianza de traspatio $(n=192)$ para la detección de anticuerpos contra el VPI3 mediante la técnica de neutralización viral. El 5.5 $\pm 2.3 \%(21 / 384)$ de las muestras tuvieron anticuerpos contra el VPI3, donde el $5.2 \pm 1.1 \%$ $(10 / 192)$ y el $5.7 \pm 1.2 \%(11 / 192)$ correspondió a animales de crianza tecnificada y de traspatio, respectivamente. Los títulos de anticuerpos tuvieron un rango de 4 a 64 y fueron detectados en animales mayores de 3 meses de edad. Los resultados indican la presencia del VPI3 en la población de cerdos.

Palabras clave: porcino, virus parainfluenza 3, anticuerpos, neutralización

\section{Abstract}

Antibodies against Parainfluenza 3 (PI3) virus were determined in pigs from commercial $(n=192)$ and backyard farms $(n=192)$. Blood samples were collected at the slaughter house from pigs of 2 to 6 months of age of any sex for detecting antibodies against the PI3 virus by viral neutralization test. The $5.5 \pm 2.3 \%$ (21/384) of the pigs had antibodies against PI3 virus, where $5.2 \pm 1.1 \%$ (10/192) and $5.7 \pm 1.2 \%$ (11/192) were from commercial and backyard farms respectively. The antibody titres ranged from 4 to 64 and were detected

\footnotetext{
${ }^{1}$ Laboratorio de Microbiología y Parasitología Veterinaria, Facultad de Medicina Veterinaria, Universidad Nacional Mayor de San Marcos, Lima

${ }^{2}$ E-mail: hriverag2005@yahoo.es
}

Recibido: 14 de setiembre de 2012

Aceptado para publicación: 25 de marzo de 2013 
in pigs older than 3 months of age. The results shows the presence of PI3 in the pig population.

Key words: pig, parainfluenza 3 virus, antibodies, virus neutralization test

\section{INTRODUCCIÓN}

La población porcina nacional es de aproximadamente 2892000 animales, donde un $20 \%$ corresponde a animales mejorados y criados con tecnología moderna a lo largo de la costa, mientras que el restante $80 \%$ está referido a porcinos criollos criados sin o con escasa tecnología, principalmente en las zonas de Sierra y Selva del país (Portal Agrario, 2008).

La industria porcina ha evolucionado en los países desarrollados gracias a los avances científicos, eficientes sistemas de manejo y al control o erradicación de enfermedades infecciosas. Sin embargo, a pesar de estos avances, los porcicultores y veterinarios de campo se enfrentan continuamente con enfermedades que inciden en el desempeño de los animales, siendo una de ellas las enfermedades respiratorias, conocidas también como complejo respiratorio porcino (CRP) (Thacker, 2001; Hansen et al., 2010; Honnold, 2010).

El CRP es resultante de una interacción entre virus y bacterias patógenas. Este problema puede exacerbarse cuando las condiciones ambientales y de manejo son inadecuadas. Los agentes virales son considerados un importante componente de este complejo, siendo los más frecuentes el virus del Síndrome Respiratorio y Reproductivo Porcino (PRRS), Influenza porcina, Aujeszky, Coronavirus Respiratorio Porcino, Parainfluenza 3, Circovirus II e Influenza porcina (Bochev, 2007) y bacterias como Mycoplasma hyopneumoniae, Actinobacillus pleuropneumoniae y Bordetella bronchiseptica (Rosete et al., 2002; Bochev, 2007; Honnold, 2010).
En el Perú, el CRP es uno de los problemas que afecta a la industria porcina (Torres et al., 2006). Entre los agentes involucrados se encuentran el virus PRRS (Alegría et al., 1998; Ramírez, 2011), Circovirus tipo II, Influenza porcina (H. Rivera, Lima, comunicación personal), Mycoplasma hyopneumoniae (Bachmann et al., 2006; Torres et al., 2006). Al parecer, $M$. hyopneumoniae es uno de los agentes prevalentes en granjas infectadas y es considerado uno de los más importantes en el desarrollo de problemas respiratorios. El virus de la parainfluenza 3 (VPI3) es de amplia difusión en bovinos y otras especies animales en el mundo, incluyendo el Perú (Rivera et al., 1994; Henrickson, 2003; Solís et al., 2010), pero su rol en el CRP no ha sido debidamente estudiado, por lo que el presente trabajo tuvo como objetivo determinar la frecuencia de anticuerpos contra el virus de la parainfluenza 3 en porcinos de crianza tecnificada y no tecnificada de la provincia de Lima.

\section{MATERIALES y Métodos}

Se colectaron muestras de sangre de 384 porcinos de ambos sexos, de 2 a 6 meses de edad, provenientes de crianza tecnificada $(n=192)$ y de traspatio $(n=192)$ de la provincia de Lima. Los animales de 5 a 6 meses fueron en su mayoría de crianza de traspatio. Los animales de 2 a 3 meses $(n=8)$ fueron incluidos debido a que el dueño manifestó que estos animales se habían recuperado de problemas respiratorios. Para la estimación del tamaño muestral se consideró una prevalencia referencial de $12.4 \%$ (Tehteh y Goyal, 1988), con un nivel de confianza de $95 \%$ y error admisible de 5\% (Daniel, 1996). Las 
Cuadro 1. Frecuencia y título de anticuerpos contra el Virus de Parainfluenza 3 (VPI3) en porcinos procedentes de crianzas tecnificadas y de traspatio en la provincia de Lima (2008)

\begin{tabular}{lcccccc}
\hline \multirow{2}{*}{$\begin{array}{l}\text { Tipo de } \\
\text { crianza }\end{array}$} & $\begin{array}{c}\text { N. }{ }^{\circ} \text { de } \\
\text { animales }\end{array}$ & \multicolumn{2}{c}{$\begin{array}{c}\text { Anticuerpos contra } \\
\text { VPI3 }\end{array}$} & \multicolumn{2}{c}{$\begin{array}{c}\text { Título de anticuerpos contra VPI3 } \\
\text { (inversa de la dilución) }\end{array}$} \\
\cline { 3 - 8 } & 192 & 10 & $5.2 \pm 1.1$ & 6 & 4 & 0 \\
\hline Tecnificada & 192 & 11 & $5.7 \pm 1.2$ & 8 & 2 & 1 \\
Traspatio & 192 & 21 & $5.5 \pm 2.3$ & 14 & 6 & 1 \\
\hline Total & 384 & 21 & $4-8$ & $64-128$ \\
\hline
\end{tabular}

${ }^{1}$ Intervalo de confianza del $95 \%$

muestras de sangre fueron obtenidas durante el beneficio en mataderos en un periodo de 60 días. Los sueros fueron obtenidos por centrifugación y conservados a $-20{ }^{\circ} \mathrm{C}$.

La detección de anticuerpos contra el VPI3 se hizo mediante la prueba de neutralización viral según el protocolo disponible en el Laboratorio de Virología de la Facultad de Medicina Veterinaria de la Universidad Nacional Mayor de San Marcos, utilizando como antígeno a la cepa SF-4 del VPI3 con título de $10^{-5} \mathrm{DI}_{50} \mathrm{CC} / 50 \mu \mathrm{l}$ y células de cornete nasal de feto bovino como sistema indicador. El suero fue considerado positivo a anticuerpos contra el VPI3 al ser capaz de neutralizar $100 \mathrm{DI}_{50} \mathrm{CC} / 50 \mu \mathrm{l}$ del virus. Un título de anticuerpo igual o mayor a 1:4 fue considerado como positivo.

\section{Resultados y Discusión}

El $5.5 \pm 2.3 \%$ (21/384) de las muestras presentó anticuerpos contra el VPI3, donde el $5.2 \pm 1.1 \%(10 / 192)$ correspondió a porcinos de crianza tecnificada y $5.7 \pm 1.2 \%$ $(11 / 192)$ a porcinos de crianza no tecnificada o de traspatio (Cuadro 1). El título de anticuerpos fluctuó entre 1:4 y 1:64, correspondiendo el mayor título en una muestra proveniente de una crianza no tecnificada (Cuadro 1).

La frecuencia de anticuerpos contra el VPI3 mostró un patrón similar en ambos tipos de crianza (Cuadro 2). Si se compara este resultado con otros reportes en la población bovina del país, se puede afirmar que el virus no está muy difundido en la población porcina. Esta baja frecuencia de la infección viral podría deberse a la ausencia de contacto con rumiantes infectados con el virus PI3. A diferencia, la prevalencia del VPI3 en establos lecheros del valle de Lurín, Lima, es más del $70 \%$ y los casos de problemas respiratorios en terneros pueden llegar hasta 99\% (Rivera et al., 1994).

La situación sanitaria frente a este virus posiblemente sea diferente en cerdos criollos de la sierra y selva, ya que la crianza mixta existente en esas zonas promueve infecciones que cruzan la barrera de especie. Una característica del VPI3 y de los otros virus respiratorios en bovinos es su rápida difusión en poblaciones animales susceptibles, ocasionando una severa disfunción de los mecanismos de defensa, sobre todo de las defensas innatas, favoreciendo la invasión de agentes bacterianos o virales (Waddilove, 1997; Thacker y Thanawongnuwech, 2002). 
Cuadro 2. Frecuencia de anticuerpos contra el Virus de la Parainfluenza 3 (VPI3) en porcinos procedentes de crianza tecnificada y de traspatio en la provincia de Lima, según edad (2008)

\begin{tabular}{|c|c|c|c|c|c|}
\hline \multirow{2}{*}{$\begin{array}{l}\text { Edad } \\
\text { (meses) }\end{array}$} & \multirow{2}{*}{$\begin{array}{c}\mathrm{N} .^{\circ} \mathrm{de} \\
\text { animales }\end{array}$} & \multicolumn{2}{|c|}{ Crianza tecnificada } & \multicolumn{2}{|c|}{ Traspatio } \\
\hline & & $\begin{array}{l}\text { Muestreados } \\
\text { (n) }\end{array}$ & $\begin{array}{c}\text { Seropositivos } \\
\text { a VPI3 (\%) }\end{array}$ & $\begin{array}{l}\text { Muestreados } \\
\text { (n) }\end{array}$ & $\begin{array}{c}\text { Seropositivos } \\
\text { a VPI3 (\%) }\end{array}$ \\
\hline 2 a 3 & 8 & 0 & - & 8 & - \\
\hline 4 a 5 & 273 & 186 & 4.8 & 87 & 2.3 \\
\hline 6 & 103 & 6 & 16.7 & 97 & 9.3 \\
\hline Total & 384 & 192 & 5.2 & 192 & 5.7 \\
\hline
\end{tabular}

La seroprevalencia detectada en el presente estudio es similar a los hallazgos de Tehteh y Goyal (1988) quienes reportaron $12.4 \%$ de anticuerpos en porcinos durante el beneficio en Minnesota, EEUU. El desarrollo de la porcicultura exige el uso de severas medidas de bioseguridad por lo que posiblemente en Minnesota, conocido como parte del cinturón porcino, el VPI3 haya tenido una baja prevalencia (Pigs-Misset, 1996). La crianza porcina de traspatio ubicada al norte, este y sur de la ciudad de Lima carece de bioseguridad pero tampoco hay contacto con rumiantes como sucede en la sierra y selva del país. La falta de uniformidad en cuanto a número de animales por edad en el presente estudio no permite concluir sobre la participación del VPI3 en el complejo respiratorio porcino observado en ambos tipos de crianza, pero la baja seroprevalencia detectada en porcinos de granjas tecnificadas sugiere una escasa actividad del VPI3. Sin embargo, sería interesante conocer el rol de este virus en los problemas respiratorios de los porcinos de la sierra, dado que se encontró una seroprevalencia del VPI3 de $87.4 \%$ en bovinos del Cusco (Solís et al., 2010), de 67.5\% en alpacas con procesos neumónicos en Puno (Victorio et al., 2004) y de $23.8 \%$ en alpacas aparentemente normales del Cusco (Cabello et al., 2006).

\section{Literatura Citada}

1. Alegría M, Rivera H, Manchego A. 1998. Evidencia del virus del síndrome reproductivo y respiratorio porcino (PRRS) en porcinos de crianza tecnificada. Rev Inv Pec IVITA 9(1): 53-58.

2. Bachmann VC, Calle S, Torres M, Gavidia C, Morales S, Acosta F. 2006. Dinámica de la infección con Mycoplasma hyopneumoniae en porcinos provenientes de madres con y sin antecedentes de inmunización. Rev Inv Vet Perú 17: 51-57.

3. Bochev I. 2007. Porcine respiratory disease complex (PRDC). Bulg J Vet Med 10: 131-146.

4. Cabello K, Quispe R, Rivera H. 2006. Frecuencia de los virus parainfluenza-3, respiratorio sincitial bovino y diarrea viral bovina en un rebaño mixto de una comunidad campesina de Cusco. Rev Inv Vet Perú 17: 167-172.

5. Daniel W. 1996. Bioestadística: base para el análisis de las ciencias de la salud. $5^{\text {a }}$ ed. México DF: Ed Limusa. 183 p. Especial de Enfermedades Respiratorias. 1996. Pig Misset. p 3-31.

6. Hansen MS, Pors SE, Jensen HE, BilleHansen V, Bisgaard M, Flechs EM, Nielsen OL. 2010. An investigation 
of the pathology and pathogens associated with porcine respiratory disease complex in Denmark. J Com Pathol 143: 120-131.

7. Henrickson KJ. 2003. Parainfluenza viruses. Clin Microbiol Rev 16: 242-264.

8. Honnold C. 2010. Porcine respiratory disease complex. [Internet], [10 april 2010]. Available in: http://www.ces.purdue.edu/ pork/health/caryhonnold.html

8. Portal Agrario. 2008. Ministerio de Agricultura, Lima. [Internet], [07 noviembre 2008]. Disponible en: http:// www.minag.gob.pe/

9. Ramírez M. 2011. Aislamiento y genotipificación del virus del Síndrome Respiratorio y Reproductivo Porcino de granjas seropositivas de las provincias de Lima y Arequipa. Tesis de Magíster. Lima: Univ Nacional Mayor de San Marcos. 89 p.

10. Rivera H, Manchego A, Sandoval N, Morales C, Flores E. 1994. Complejo respiratorio bovino en terneros del valle de Lima. Rev Inv Pec IVITA 7(1): 35-38.

11. Rosete D, Archundia J, Cabello C, Manjares M. 2002. Patogenia de las infecciones respiratorias por virus. Rev Inst Nal Enf Resp Mex 15: 239-254.
12. Solís G, Rivera H, Falcón N. 2010. Evaluación serológica de los Virus Respiratorio Sincitial (VRS) y Parainfluenza 3 (PI3) en bovinos de cusco. Rev Inv Vet Perú 21: 204-209.

13. Tacker LE. 2001. Immunology of the porcine respiratory disease complex. Vet Clin N Am Food A 17: 551-565.

14. Tehteh E, Goyal S. 1988. Antibodies to Parainfluenza virus type 3 in Minnesota swine. Br Vet J 144: 613-616.

15. Thacker $E$, Thanawongnuwech $R$. 2002. Porcine respiratory disease complex (PRDC). Thai J Vet Med 32: 125-134.

16. Torres M, Calle S. Rivera H, Camacho C, Falcón N, Alzamora C. 2006. Determinación serológica de la infección con Mycoplasma hyopneumoniae en una granja porcina de Lima. Rev Inv Vet Perú 17: 58-63.

17. Victorio W, Rosadio R, Rivera $\boldsymbol{H}$. 2004. Seroprevalencia de virus neumopatógenos en alpacas adultas de la provincia de Canchis, Cusco. Rev Inv Vet Perú 15: 127-131.

18. Waddilove J. 1997. Virus inmunosupresivos. Un nuevo modelo de enfermedades porcinas. Ind Porcina 17(1): 11-12. 